\title{
Prevalence and molecular characterization of Escherichia coli isolates during radish sprout production in the Republic of Korea
}

\author{
Nagendran Rajalingam', Jae-Hyun Yoon', Bohyun Yoon², Nguyen Bao Hung ${ }^{1,5}$, Won-II Kim', Hyunju Kim³, \\ Byeong Yong Park ${ }^{4}$ and Se-Ri Kim ${ }^{1,6^{*}}$ (I)
}

\begin{abstract}
This study was conducted to investigate the prevalence of coliforms and Escherichia coli across radish sprout production facilities in the Republic of Korea and to characterize isolated E. coli. A total of 324 samples were collected from three different radish sprout production units in spring and summer. Overall, the levels of coliforms were significantly higher (>3.75 log CFU/g) in radish sprouts during summer season than in spring. E. coli was detected in the pre-harvest (50\%) and post-harvest (39\%) sprouts and water samples (33\%) from farms B and C. Of the 48 E. coli isolates, five E. coli isolates were positive for the eaeA gene, indicative of EPEC O110, two isolates were eaeA-positive (EPEC ONT) and one isolate was ipaH-positive (ETEC O71). These three E. coli strains were identified as novel sequence types by the multilocus sequence-typing assay based on the combination of allelic profiles. In addition, the EPEC O110 isolates obtained from the stream water stored in container of farm C were toxic to Caenorhabditis elegans. It is necessary to implement safety measures during the production of radish sprouts to prevent $E$. coli outbreaks.
\end{abstract}

Keywords: Escherichia coli, Radish sprout, Multilocus sequence typing (MLST), Toxicity

\section{Introduction}

Due to consumer demands for healthy and natural food products, seed sprouts with antioxidant and anti-tumor properties have gained worldwide popularity $[1,2]$. This growing demand has been accompanied by an increase in bacterial outbreaks associated with sprouted seed products [3].

In the last four decades, several outbreaks linked with seed sprouts have been reported in several countries [4]. The world's largest foodborne outbreak was caused by Escherichia coli $\mathrm{O} 157: \mathrm{H} 7$, which involved more than 7,000 patients, was associated with white radish sprout consumption in Japan [5]. A massive outbreak of EHEC

\footnotetext{
*Correspondence: seri81@korea.kr

${ }^{6}$ Agro-Food Safety \& Crop Protection Department, National Institution of Agricultural Science, Rural Development Administration, Wanju 55365 South Korea

Full list of author information is available at the end of the article
}

O104:H4 linked with the fenugreek sprouts caused illness in 6,829 patients and 53 deaths in Germany during the summer of 2011 [6]. In the same year, 29 people were infected with EHEC O26 after consuming raw clover sprouts served in the Jimmy John's restaurant, USA [7]. Moreover, a multistate EHEC O103 outbreak involving 51 people linked to clover sprouts was reported in the USA [8].

Microbial contamination in sprouts can occur from numerous sources, including contaminated seeds, soil, fertilizer, tools, and the water used during the pre- and post-harvest processing stages [9]. Preharvest sprout contamination may occur from substandard water, soil, and the close proximity of cattle rearing facilities [10], while postharvest contamination may occur during packing, transport, and storage $[11,12]$. Coliforms are group of closely related harmless bacteria that are widespread throughout the environment including soil and water. The level of coliform bacteria indicates the microbial 
quality of the food product and generally reflects the hygienic practices followed during food production or handling [13].

Laboratory-based monitoring of sprout producing units and the frequent safety evaluation of the farm tools and materials used during the production process can help to identify the source of contamination and prevent disease outbreaks. Thus, we collected samples from all the materials used in sprout production, including seeds, sprouts, water, farming, and packing tools from various sprout production companies and analyzed them for the presence of pathogenic $E$. coli. The isolated strains were discriminated into subgroups by serotyping and further characterized at the molecular level using multiplex polymerase chain reaction (PCR) and multilocus sequence typing (MLST) and genetic relatedness between the isolates. In addition, the toxicity of the isolates was determined using Caenorhabditis elegans. The results of this study provide information about the prevalence and characteristics of $E$. coli isolates recovered from radish sprout production environments.

\section{Materials and methods Sampling}

Three hundred twenty-four samples, including radish seeds $(n=18)$, preharvest sprouts $(n=54)$, postharvest sprouts $(\mathrm{n}=18)$, ground water pumped from well $(n=18)$, irrigation water i.e. water passed from well through pipes to sprouts directly $(n=18)$, stream water $(n=6)$. Agricultural materials nutrient solutions A $(n=18), B(n=18)$ and $A+B(n=18)$, cultivation equipments including nutrients storage tank $(\mathrm{n}=18)$, fabric $(n=18)$, tray $(n=18)$, basket $(n=18)$ and postharvest equipments knife $(n=18)$, cutting board $(n=15)$, packing material $(n=15)$ and glove $(n=18)$, were collected twice from three radish sprout facilities located in Gyeonggi-do, Republic of Korea, during April-May and August 2016. The radish sprouts were cultivated hydroponically in all the farms. The farms A and B used ground water and irrigation water for radish sprout cultivation while farm $C$ used stream water along with ground water for irrigation without filtration or disinfection.

Surfaces of nutrients storage tank, fabric, tray, basket, knife, cutting board and packing material were swabbed with commercial kit, and glove samples were collected using the glove-juice method [14]. Seeds and radish sprouts (200 geach) from the cultivation and postharvest steps were collected and placed in sterile plastic bags. For hydroponic farming, the farms diluted nutrient solutions $\mathrm{A}$ and $\mathrm{B}$ with water and delivered them through irrigation water to the sprouts two days post germination. Two-liter water and nutrient solutions were individually collected in sterile bottles.

\section{Analysis of coliform and Escherichia coli}

For the quantitative analysis of coliforms and E. coli, $25 \mathrm{~g}$ of seed and sprout samples were placed in $225 \mathrm{ml}$ of $0.1 \%$ peptone water (PW) (Oxoid, Basingstoke, UK) and homogenized in a BagMixer ${ }^{\circledR}$ (Interscience, SaintNom-la-Bretéche, France). Surface samples were homogenized using a vortex prior to dilution. These pretreated samples were serially diluted $1: 10$ in $0.1 \%$ PW and $1 \mathrm{ml}$ aliquots were inoculated on $3 \mathrm{M}^{\mathrm{TM}}$ Petrifilm ${ }^{\mathrm{TM}}$ E. coli/coliform count plates (3 M Microbiology, Minnesota, USA), followed by incubation at $37{ }^{\circ} \mathrm{C}$ for $24-48 \mathrm{~h}$. Water samples were evaluated for coliforms and $E$. coli using the Colilert-18 detection kit from IDEXX laboratories (Westbrook, Maine, USA).

For the qualitative analysis of $E$. coli and E. coli O157:H7, $25 \mathrm{~g}$ of seed and sprouts were placed in $225 \mathrm{ml}$ of $E$. coli broth (EC) (Oxoid) and modified tryptone soy broth (mTSB) (Oxoid) for E. coli and E. coli O157:H7 detection, respectively, and homogenized in a BagMixer ${ }^{\circledR}$. For the swab and glove samples, $1 \mathrm{ml}$ of homogenate was dispensed into $9 \mathrm{ml}$ of EC broth and mTSB individually. Water samples $(250 \mathrm{ml})$ were filtered using a $0.45 \mu \mathrm{m}$ membrane filter (Merck-Millipore, Carrigtwohill, Ireland). Each filter was placed in sterile bottles containing $40 \mathrm{ml}$ of EC broth or mTSB and incubated at $44{ }^{\circ} \mathrm{C}$ and $37^{\circ} \mathrm{C}$ for $24 \mathrm{~h}$, respectively. The enriched cultures were streaked onto eosin-methylene blue agar plates (Oxoid) and CHROMagar $^{\mathrm{TM}}$ E. coli O157 (CHROMagar ${ }^{\mathrm{TM}}$, Paris, France) plates for E. coli and E. coli $\mathrm{O} 157: \mathrm{H} 7$ using a disposable loop. After incubation at $37{ }^{\circ} \mathrm{C}$ for $24 \mathrm{~h}$, typical colonies were picked and identified using the VITEK 2 system, an automated system that performs microbial identification and antibiotic susceptibility testing (bioMérieux-Vitek, USA). Additionally, the E. coli isolates were further identified and classified by $16 \mathrm{~s}$ rRNA sequencing (Macrogen, Seoul, Korea) [15].

\section{Serotyping and virulence determination}

Colonies of E. coli and E. coli O157:H7 were serotyped using Escherichia coli O-antigen antisera kit (Joong Kyeom, Republic of Korea). Genomic DNA was extracted from the isolates and retention of virulence determinants (eaeA, bfpA, ipaH, aggR, vt1, vt2, lt, st) in the isolates were determined by PCR using the PowerChek ${ }^{\mathrm{TM}}$ Diarrheal E. coli 4-plex PCR Detection Premix I/Premix II kit (KogeneBioTech Co., Ltd., Republic of Korea) [16].

\section{Multi locus sequence typing (MLST)}

To determine clonal relationship of the E. coli isolates, genomic DNA of the isolates was prepared and the housekeeping genes (Table 3 ) were amplified by PCR. The resulting DNA fragments were purified and sequenced 
(GnCBio Co. Ltd., Republic of Korea). Sequence types (STs) of the E. coli isolates were assigned using the Bacterial Isolate Genome Sequence Database (BIGSdb) tool from the PubMLST server.

\section{Cytotoxicity assay}

The nematode Caenorhabditis elegans killing assay was carried out to evaluate the pathogenicity of $E$. coli isolates in compliance with Lee's method with modifications [17]. Overnight cultures of $E$. coli isolates possessing pathogenic genes $\left(2 \times 10^{9} \mathrm{CFU} / \mathrm{ml}\right)$ grown in Luria-Bertani broth at $37^{\circ} \mathrm{C}$ for $18 \mathrm{~h}$ were spread on nematode growth medium (NGM). The nematodes were synchronized by hypochlorite bleaching and subsequently cultured on NGM in the presence of E. coli. Repeatedly, synchronized L1 larvae were transferred to a new plate containing $E$. coli OP50, allowing the production of L4 larvae serially. After three days, 20 L4/young adult hermaphrodites were placed on NGM, incubated at $25{ }^{\circ} \mathrm{C}$ for $45 \mathrm{~min}$, and transferred to a new plate every single day. The survival of C. elegans without the presence of progeny and L4 nematodes was examined using the Kaplan-Meier method, and differences were determined with log-rank test.

\section{Results and discussion}

Assessment of coliforms and $E$. coli contamination in radish seed sprouts production units

The levels of coliforms and $E$. coli in the samples from sprouts, farming tools, and water from farms A, B, and C are presented in Tables 1 and 2. Of the 324 samples collected during spring and summer, the levels of coliforms were higher (>3.75 $\log \mathrm{CFU} / \mathrm{g})$ in radish sprouts in summer than in spring. Coliforms were more prevalent in tray $(4.96 \pm 1.44)$, cutting board $(5.62 \pm 0.59)$ and glove $(4.30 \pm 0.00)$ from farm A and basket $(5.57 \pm 0.49)$, cutting board $(5.40 \pm 0.93)$ and glove $(4.82 \pm 0.11)$ from B during summer season compared to all the other samples including water $(<2 \log \mathrm{CFU} / \mathrm{ml})$, agricultural materials $(<3 \log \mathrm{CFU} / \mathrm{ml})$. Corresponding to our findings, several studies have reported increased microbial levels in postharvest sprouts than in seeds $[18,20]$. The incidence of E. coli was significantly higher in the preharvest $(50 \%)$ and postharvest (39\%) sprouts and water samples (33\%) from farms B and C. E. coli was detected in the basket (5\%), glove (16\%), and knife (11\%) samples, while no $E$. coli were detected in the other samples.

Seeds usually acquire $10^{2}$ to $10^{3} \mathrm{CFU} / \mathrm{g}$ of coliforms from the surrounding environment [21]. These bacterial populations can significantly increase during the sprouting process to as high as $10^{8}$ to $10^{11} \mathrm{CFU} / \mathrm{g}$ [22, 23] without damaging the appearance of the final product [24]. Unaware of the contaminated seeds $(0.90 \pm 0.85$ $\log \mathrm{CFU} / \mathrm{g}$ ), farms $\mathrm{B}$ and $\mathrm{C}$ used the seeds for cultivation during the summer season, which resulted in a large number of coliforms in the pre- and post-harvest radish sprouts (3.75-4.92 log CFU/g).

Water can potentially cross-contaminate sprouts by transferring microbes from other sources during production and processing [25]. In this study, the seeds used for hydroponic germination in farms $\mathrm{A}$ and $\mathrm{C}$ during spring and summer were free of $E$. coli contamination. However, $E$. coli was detected in the preharvest and postharvest radish sprouts and water including ground water, irrigation water and stream water stored in container. Since water was the only source that was in contact with the seeds during sprouting, it is coherent that water transmitted E. coli to vulnerable seeds during irrigation and contaminated the sprouts. Even though knives and cutting boards were washed with water by the farms, they can still be contaminated during processing by transmitting $E$. coli from contaminated to non-contaminated fresh produce [26]. For instance, in this study, no coliforms were detected in the seeds and preharvest radish sprouts of farm A during the spring season, but during harvesting, the coliforms were transferred to the postharvest radish sprouts via contaminated knives $(3.69 \pm 0.03$ $\log \mathrm{CFU} / \mathrm{g})$ and gloves $(2.84 \pm 2.46 \mathrm{log} \mathrm{CFU} / \mathrm{g})$ used by the workers.

\section{Molecular characterization and virulence determination of $E$. coli isolates}

The E. coli isolates were discriminated into virulent and avirulent strains by identifying the presence of pathogenic genes in their genome. Of the 48-suspected E. coli isolates, only eight isolates from farms $B$ and $C$ were identified as pathogenic based on the results of serotyping and virulence determination tests (Table 3). Eight isolates belonged to the $\mathrm{O}$-serogroup, five isolates and one isolate from water were assigned as serotypes $\mathrm{O} 110$ and O71, respectively, and the other two isolates were nontypeable O-antigens (ONT). Pathogenic E. coli possess certain combinations of virulence genes that cause food poisoning [27]. Based on the combination of virulence genes, $E$. coli strains can be classified as enteropathogenic (EPEC), enterotoxigenic (ETEC), enteroinvasive (EIEC), enteroaggregative (EAEC), and enterohemorrhagic (EHEC) [28]. The O110 and ONT isolates possessed the virulence gene eaeA (E. coli attaching and effacing), while the $\mathrm{O} 71$ isolate contained the ipaH (invasion plasmid antigen $\mathrm{H}$ ) gene, which designates these isolates as EPEC O110, EPEC ONT, and ETEC O71 (Table 3).

Escherichia coli strains with serotype O110 were previously isolated from various sources in different countries, including healthy adults in Japan [29], dairy samples in France [30], and ovine strains in Spain [31]. However, all 


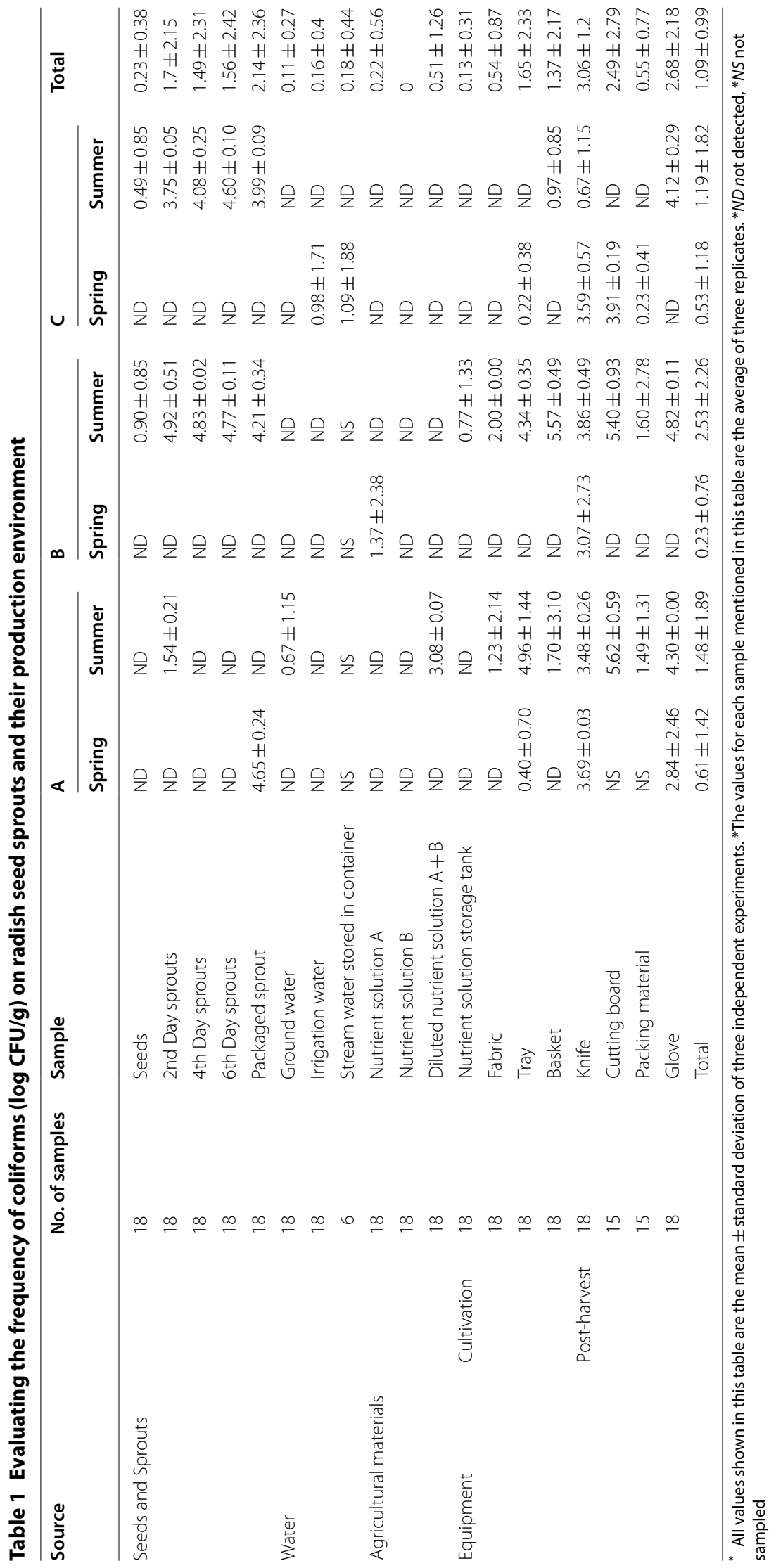




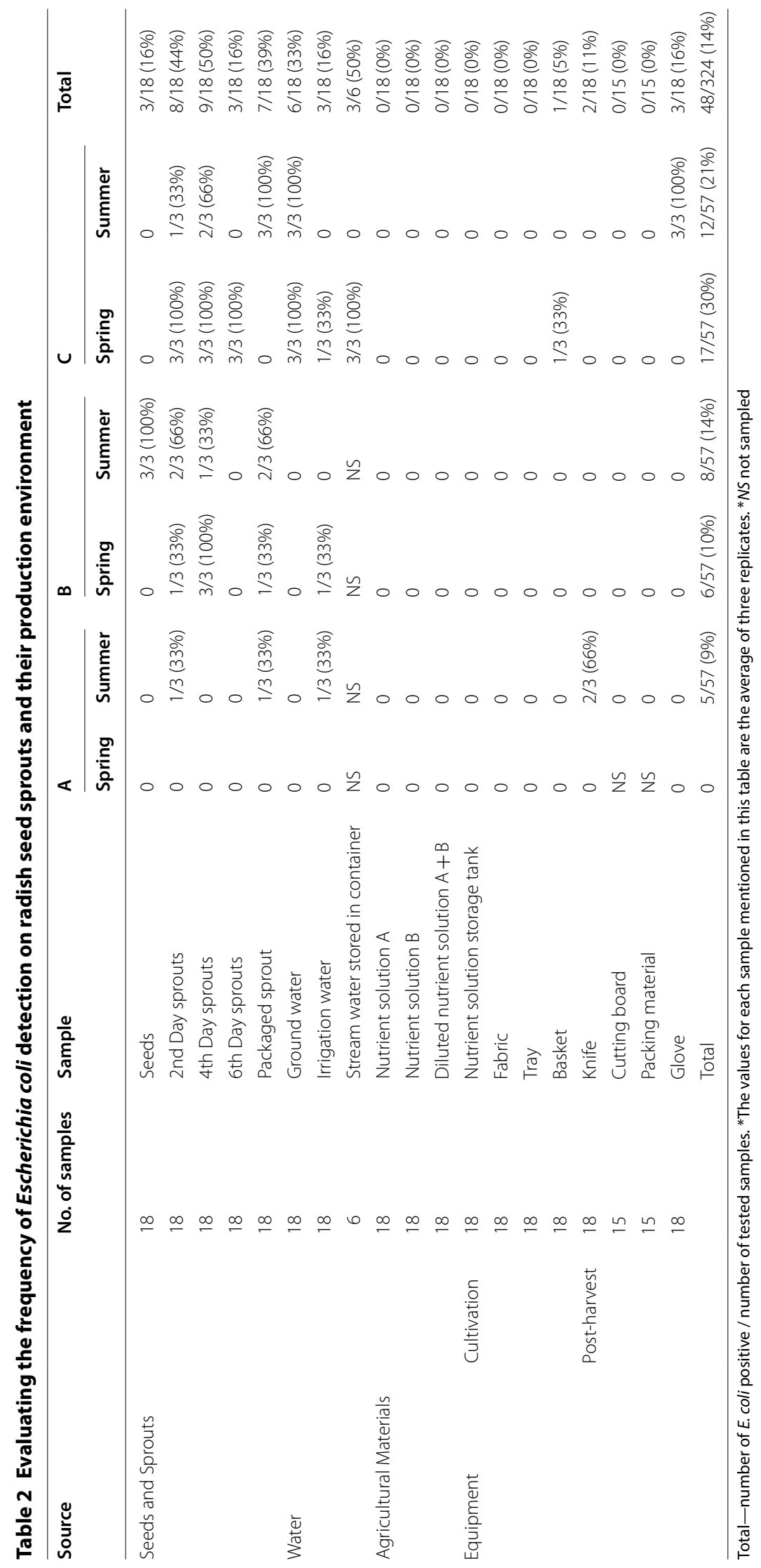


Table 3 Serological and genotypic characterization of Escherichia coli isolates

\begin{tabular}{|c|c|c|c|c|c|c|c|c|c|c|c|c|c|c|c|}
\hline \multirow[t]{2}{*}{ E. coli isolate } & \multirow[t]{2}{*}{ Farm } & \multirow[t]{2}{*}{ Season } & \multirow[t]{2}{*}{ Source } & \multirow[t]{2}{*}{$\begin{array}{l}\text { No. } \\
\text { of isolates }\end{array}$} & \multicolumn{2}{|c|}{$\begin{array}{l}\text { Virulence } \\
\text { genes }\end{array}$} & \multicolumn{8}{|c|}{ E. coli allelic profile (MLST) } & \multirow[t]{2}{*}{ ST } \\
\hline & & & & & eaeA & ipaH & $\operatorname{din} B$ & $i c d A$ & $p a b B$ & polB & putP & $\operatorname{trpA}$ & $\operatorname{trp} B$ & uidA & \\
\hline EPEC 0110 & C & Spring & Container water & 5 & + & - & 1 & 23 & 11 & 9 & 2 & 144 & 46 & 137 & Trev \\
\hline EPEC ONT & C & Spring & Container water & 2 & + & - & 1 & 23 & 11 & 9 & 2 & 144 & 46 & 137 & New \\
\hline ETEC O71 & B & Summer & Irrigation water & 1 & - & + & 11 & 35 & 4 & 52 & 125 & 146 & 141 & 2 & New \\
\hline
\end{tabular}

* The numbers in the MLST column represent the number of alleles per locus; ST sequence types

the O110 isolates possessed either one of the Shiga-toxin genes (stx 1 and stx2), but none were eaeA-positive. The $e a e A$ gene codes for the surface protein Intimin, a virulence factor usually found in EPEC $(\mathrm{O} 127: \mathrm{H} 6)$ and EHEC (O157:H7) strains [32]. Intimins localize to the outer membrane of $E$. coli cells and promote intimate bacterial adhesion to the intestinal epithelia, resulting in the formation of effacing lesions that are necessary for causing EPEC and EHEC diarrhea [33]. The ETEC O71 serotype strains were isolated from patients with enteric illness in Brazil [34] and Vietnam [35]. The similarity between the strains was the presence of the eaeA gene; however, the strain isolated in our study was eaeA-negative and $i p a H-$ positive (Table 3). The $i p a H$ gene is a type 3 effector that facilitates the penetration of pathogens into intestinal cells [36]. The MLST database revealed three different STs that did not exactly match with other STs in the database (Table 3), indicating that the isolates could be new subtypes.

\section{Evaluation of cytotoxicity of $E$. coli isolates using Caenorhabditis elegans}

The cytotoxicity of the E. coli isolates was determined by comparing the survival rate of isolate-exposed C. elegans with that of those exposed to E. coli OP50. The survival rate of those exposed to the E. coli isolate EPEC O110 was significantly reduced from day 8 compared to $E$. coli OP50, which showed a reduction on day 12, indicating that the isolate EPEC O110 is pathogenic (Fig. 1). The isolates EPEC ONT and ETEC O71 caused survival rates similar to those of E. coli OP50, indicating that the isolates were non-pathogenic. Merkx-Jacques et al. (2013) demonstrated that the $E$. coli isolates that were predicted to be pathogenic by genotyping assays were able to kill $C$. elegans [37]. Correspondingly, in our study, only one of the eight isolates was a toxin producing $E$. coli.

\section{Conclusion}

The aim of this study was to identify the source of $E$. coli contamination in commercial radish production units and emphasize the need to minimize contamination by following good agricultural practices during sprout production and good hygienic practices during processing, packaging, and shipping. Genotyping and toxicity studies revealed that the pathogenic E. coli strain EPEC O110 was more prevalent in the stream water stored in the containers from farm $C$. The contaminated water may have potentially transferred pathogenic E. coli to the germinated seeds and sprouts during production and processing. In addition, the knives, cutting boards, trays and
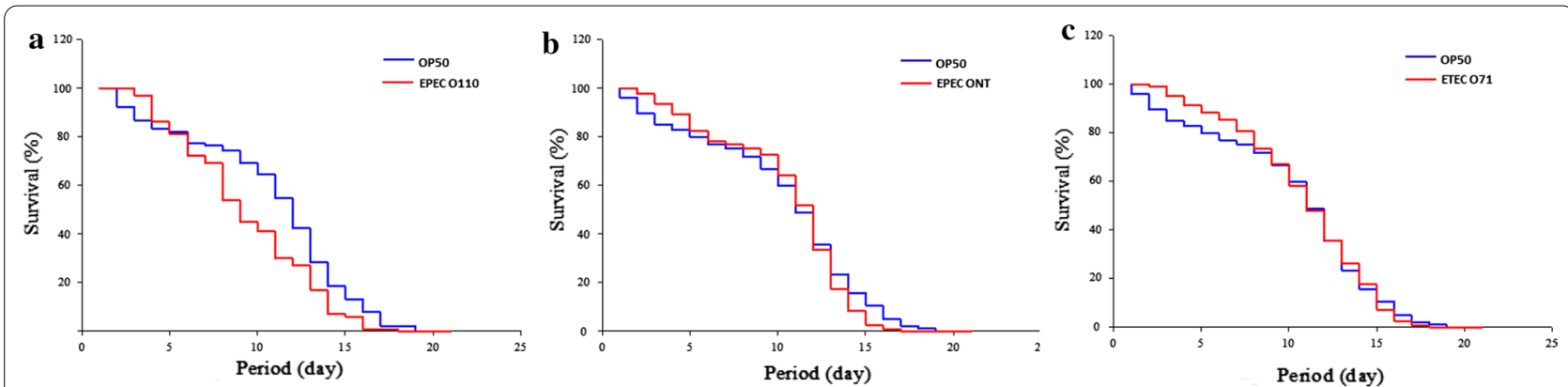

Fig. 1 Kaplan-Meier survival plots of Caenorhabditis elegans infected with Escherichia coli isolates. The nematode worms grown in nematode growth medium were fed with three different E. coli isolates (EPEC 0110, EPEC ONT and ETEC O71) along with control E. coli OP50 and incubated at $25^{\circ} \mathrm{C}$. The mortality of the worms was monitored every day and the data were generated using the Kaplan-Meier method. Blue line indicates the survival of nematodes fed with E. coli OP50 while the red line indicates the mortality of the worms fed with E. coli isolates a EPEC 0110, $\mathbf{b}$ EPEC ONT, and c ETEC O71 
gloves used during the processing of sprouts may have transmitted the pathogens through cross-contamination. The prevalence of diarrhea causing $E$. coli in the water that is stored in the container in radish sprout production units accentuates the need to sanitize stream water before irrigation and routinely clean the containers and other equipments at regular intervals.

\section{Authors' contributions}

NR and JHY contributed to the writing of the manuscript and performed the majority of data analysis. BY, NBH, WK, HK performed experiments and prepared raw materials. BYP contributed to the discussion of experimental results. SRK planned and led this research. All authors read and approved the final manuscript.

\section{Funding}

This study was funded by the National Institution of Agricultural Science, Rural Development Administration, Republic of Korea.

\section{Availability of data and materials}

All the data analyzed during this study are included in this article.

\section{Competing interests}

The authors declare that they have no competing interests.

\section{Author details}

1 Rural Development Administration, Microbial Safety Team, National Institute of Agricultural Sciences, Wanju 55365, Republic of Korea. ${ }^{2}$ Department of Animal Science and Institute of Milk Genomics, Chonbuk National University, Jeonju 54896, Korea. ${ }^{3}$ Crop Foundation Division, National Institute of Crop Sciences (NICS), Rural Development Administration (RDA), Wanju 55365, Republic of Korea. ${ }^{4}$ Research Policy Bureau, Research Policy Division, Rural Development Administration (RDA), Jeonju 54875, Republic of Korea. ${ }^{5}$ Laboratory of Enzyme and Protein Technology, Institute of Biotechnology, Hue University, Hue 530000, Vietnam. ${ }^{6}$ Agro-Food Safety \& Crop Protection Department, National Institution of Agricultural Science, Rural Development Administration, Wanju 55365, South Korea.

Received: 23 November 2020 Accepted: 5 February 2021 Published online: 08 March 2021

\section{References}

1. Yuan G, Wang X, Guo R, Wang Q (2010) Effect of salt stress on phenolic compounds, glucosinolates, myrosinase and antioxidant activity in radish sprouts. Food Chem 121(4):1014-1019

2. Neetoo H, Chen $\mathrm{H}$ (2010) Pre-soaking of seeds enhances pressure inactivation of E. coli O157: H7 and Salmonella spp. on crimson clover, red clover, radish and broccoli seeds. Int J Food Microbiol. 137(2-3):274-280

3. Kim Y, Kim H, Song M, Rhee MS (2015) Decontamination method using heat and relative humidity for radish seeds achieves a 7-log reduction of Escherichia coli O157: $\mathrm{H7}$ without affecting product quality. Int J Food Microbiol. 201:42-46

4. Kintz E, Byrne L, Jenkins C, McCARTHY N, Vivancos R, Hunter P (2019) Outbreaks of shiga toxin-producing escherichia coli linked to sprouted seeds, salad, and leafy greens: a systematic review. J Food Prot 82(11):1950-1958

5. Michino H, Araki K, Minami S, Takaya S, Sakai N, Miyazaki M et al (1999) Massive Outbreak of Escherichia coli O157: H7 Infection In Schoolchildren in Sakai City, Japan, Associated with Consumption of White Radish Sprouts. Am J Epidemiol 150(8):787-796

6. Karch H, Denamur E, Dobrindt U, Finlay BB, Hengge R, Johannes L et al (2012) The enemy within us: lessons from the 2011 European Escherichia coli 0104: H4 outbreak. EMBO Molecular Med 4(9):841-848

7. Centers for Disease Control and Prevention. Multistate Outbreak of Shiga Toxin-producing Escherichia coli O26 Infections Linked to Raw Clover
Sprouts at Jimmy John's Restaurants 2012 [https://www.cdc.gov/ecoli /2012/o26-02-12/index.html].

8. Centers for Disease Control and Prevention. Outbreak of E. coli Infections Linked to Clover Sprouts 2020 [https://www.cdc.gov/ecoli/2020/o103h 2-02-20/index.html].

9. Sagoo S, Little C, Ward L, Gillespie I, Mitchell RT (2003) Microbiological study of ready-to-eat salad vegetables from retail establishments uncovers a national outbreak of salmonellosis. J Food Prot 66(3):403-409

10. Pachepsky Y, Shelton DR, McLain JE, Patel J, Mandrell RE. Irrigation waters as a source of pathogenic microorganisms in produce: a review. Advances in Agronomy. 113: Elsevier; 2011. p. 75-141.

11. Benincasa P, Falcinelli B, Lutts S, Stagnari F, Galieni A (2019) Sprouted Grains: A Comprehensive Review. Nutrients 11(2):421

12. Machado-Moreira B, Richards K, Brennan F, Abram F, Burgess CM (2019) Microbial Contamination of Fresh Produce: What, Where, and How? Comprehensive Rev Food Sci Food Safety 18(6):1727-1750

13. Brandt MJ, Johnson KM, Elphinston AJ, Ratnayaka DD (2017) Chapter 7 - Chemistry, Microbiology and Biology of Water. In: Brandt MJ, Johnson KM, Elphinston AJ, Ratnayaka DD (eds) Twort's Water Supply, 7th edn. Butterworth-Heinemann, Boston, pp 235-321

14. Yoon Y, Kim S-R, Kang D-H, Shim W-B, Seo E, Chung D-H (2008) Microbial Assessment in School Foodservices and Recommendations for Food Safety Improvement 73(6):M304-M313

15. Perveen N, Muzaffar SB, Vijayan R, Al-Deeb MA (2020) Microbial communities associated with the camel tick, Hyalomma dromedarii: 16S rRNA gene-based analysis. Scientific Reports 10(1):17035

16. Yun B, Kim Y, Hung NB, Oh K-H, Kim W-I, Ham H et al (2018) Microbiological quality and characteristics of isolated Escherichia coli in irrigation water used in Napa cabbage cultivation. Applied Biological Chemistry 61(5):567-574

17. Lee S-J, Kenyon C (2009) Regulation of the longevity response to temperature by thermosensory neurons in Caenorhabditis elegans. Curr Biol 19(9):715-722

18. Fu T-J, Reineke KF, Chirtel S, Vanpelt OM (2008) Factors influencing the growth of Salmonella during sprouting of naturally contaminated alfalfa seeds. J Food Prot 71(5):888-896

19. Yang Y, Meier F, Ann Lo J, Yuan W, Lee Pei Sze V, Chung HJ et al (2013) Overview of recent events in the microbiological safety of sprouts and new intervention technologies. Comprehensive Rev Food Sci Food Safety. 12(3):265-280

20. Landry KS, Sela DA, McLandsborough $L$ (2018) Influence of sprouting environment on the microbiota of sprouts. J Food Saf 38(1):e12380

21. Feng P (1997) A summary of background information and foodborne illness associated with the consumption of sprouts. Center for Food Safety and Applied Nutrition, Washington, DC, pp 96-99

22. Gandhi M, Matthews KR (2003) Efficacy of chlorine and calcinated calcium treatment of alfalfa seeds and sprouts to eliminate Salmonella. Int J Food Microbiol 87(3):301-306

23. Peñas E, Gómez R, Frías J, Vidal-Valverde C (2008) Application of highpressure treatment on alfalfa (Medicago sativa) and mung bean (Vigna radiata) seeds to enhance the microbiological safety of their sprouts. Food Control 19(7):698-705

24. Taormina PJ, Beuchat $L R$, Slutsker $L$ (1999) Infections associated with eating seed sprouts: an international concern. Emerg Infect Dis 5(5):626

25. Decol LT, Casarin LS, Hessel CT, Batista ACF, Allende A, Tondo EC (2017) Microbial quality of irrigation water used in leafy green production in Southern Brazil and its relationship with produce safety. Food Microbiol 65:105-113

26. Yang Y, Luo Y, Millner P, Turner E, Feng H (2012) Assessment of Escherichia coli O157: H7 transference from soil to iceberg lettuce via a contaminated field coring harvesting knife. Int J Food Microbiol 153(3):345-350

27. Grauke LJ, Kudva IT, Yoon JW, Hunt CW, Williams CJ, Hovde CJ (2002) Gastrointestinal tract location of Escherichia coli O157: H7 in ruminants. Appl Environ Microbiol 68(5):2269-2277

28. Chapman TA, Wu X-Y, Barchia I, Bettelheim KA, Driesen S, Trott D et al (2006) Comparison of virulence gene profiles of Escherichia coli strains isolated from healthy and diarrheic swine. Appl Environ Microbiol 72(7):4782-4795

29. Morita-Ishihara T, lyoda S, Iguchi A, Ohnishi M (2016) Secondary Shiga Toxin-Producing Escherichia coli Infection, Japan, 2010-2012. Emerg Infect Dis 22(12):2181 
30. Pradel N, Bertin Y, Martin C, Livrelli V (2008) Molecular analysis of shiga toxin-producing Escherichia coli strains isolated from hemolytic-uremic syndrome patients and dairy samples in France. Appl Environ Microbiol 74(7):2118-2128

31. Blanco M, Blanco JE, Mora A, Rey J, Alonso JM, Hermoso M, Hermoso J, Alonso MP, Dahbi G, González EA, Bernárdez MI (2003) Serotypes, virulence genes, and intimin types of Shiga toxin (verotoxin)-producing Escherichia coli isolates from healthy sheep in Spain. J Clin Microbiol 41(4):1351-1356

32. Adams TM, Schmoldt H-U, Kolmar H (2004) FACS screening of combinatorial peptide and protein librariers displayed on the surface of Escherichia coli cells. Evolutionary Methods in Biotechnology: Clever Tricks for Directed Evolution 1:31-46

33. Jerse AE, Yu J, Tall BD, Kaper JB (1990) A genetic locus of enteropathogenic Escherichia coli necessary for the production of attaching and effacing lesions on tissue culture cells. Proc Natl Acad Sci 87(20):7839-7843

34. Ori EL, Takagi EH, Andrade TS, Miguel BT, Cergole-Novella MC, Guth BE, Hernandes RT, Dias RC, Pinheiro SR, Camargo CH, Romero EC. Diarrhoeagenic Escherichia coli and Escherichia albertii in Brazil: pathotypes and serotypes over a 6-year period of surveillance. Epidemiology \& Infection. 2019;147.

35. Hien BT, Scheutz F, Cam PD, Serichantalergs O, Huong TT, Thu TM, Dalsgaard A (2008) Diarrheagenic Escherichia coli and Shigella strains isolated from children in a hospital case-control study in Hanoi. Vietnam J Clin Microbiol 46(3):996-1004

36. Das A, Mandal J (2019) Extensive inter-strain diversity among clinical isolates of Shigella flexneri with reference to its serotype, virulence traits and plasmid incompatibility types, a study from south India over a 6-year period. Gut Pathogens 11(1):33

37. Merkx-Jacques A, Coors A, Brousseau R, Masson L, Mazza A, Tien YC, Topp E (2013) Evaluating the pathogenic potential of environmental Escherichia coli by using the Caenorhabditis elegans infection model. Appl Environ Microbiol 79(7):2435-2445

\section{Publisher's Note}

Springer Nature remains neutral with regard to jurisdictional claims in published maps and institutional affiliations.

\section{Submit your manuscript to a SpringerOpen ${ }^{\circ}$ journal and benefit from:}

- Convenient online submission

- Rigorous peer review

- Open access: articles freely available online

- High visibility within the field

- Retaining the copyright to your article

Submit your next manuscript at $\boldsymbol{\nabla}$ springeropen.com 